エッセイ

\title{
生体とロボット 一特集を企画してー
}

8 月の下旬に 1 週間程中国を訪問する機会を得 た。目的は中国科学技術委員会主催の先端口ボッ トワークショップに出席するためである。現在中 国では 2 つのロボットに関するナショナルプロジ ェクトが進められているという。一つは産業用口 ボット、もら一つは先端ロボットの研究開発であ る。前者は主に工場における生産の自動化を推進 するためのロボットを開発することを主眼として いる。また後者では、原子力プラントや海洋開発 など、いわゆる極限作業への適用を対象とした口 ボットの研究が進められている。ワークショップ には私の他にドイッから 2 名、米国から 2 名の研 究者が招待された。参加者各々が自国のロボット 研究の現状を紹介すると共に、中国のナショナル プロジェクトに対して種々討論するのがワークシ ョップの中心課題であった。

ここで話題になったことの一つは、高度なロボ ットがはたして生産の自動化に役立つかというこ とである。中国のプロジェクトリーダの一人は、

「中国では人手は十分あるが、製品の品質向上に は生産の機械化が必要」とした上で、「もし人に 近いロボットができれば、人手に頼っている現状 のラインの構成を変えなくても、人をロボットに 置き換えることができる。従って、頭のよい高度 なロボットの開発は工場の再設計に伴ら設備投資 を最小にして自動化を達成する上でぜひとも必要 だ。」という趣旨のことを述べ、この思想にした がって、中国のナショナルプロジェクトではイン テリジェントなロボットを重視した研究が進めら れていると説明した。この説明からもわかるよう に中国のナショナルプロジェクトの一つの特長は、

平成 3年 10 月 17 日受付

*機械技術研究所

干305 茨城県つくば市並木 1-2
高度なロボットを作業の自動化の強力なツールと 位置づけていることである。これに対し私は多少 否定的な意見を述べてきた。日本の実情からすれ ば、いわゆるロボット研究者が研究しているセン サ付の知能口ボットを生産ラインに導入している 例はそう多くはない。技術的に成熟している位置 制御機能しか持たない単純繰り返しロボットの方 がよく使われている。製造業各社には多くの生産 技術者が扣り、そらした単純なロボットでも十分 作業ができるように工場のラインを設計し、生産 性の高い自動化ラインを構成しているのが通例で ある。高度に自動化された AF 工場を見学しても、 高䄲な知能やセンサを持つロボットが活躍してい る椂子は余り見られない。研究成果が実用口ボッ トに生かされないことから、企業のロボット研究 者は上司から「いつになったら使える口ボットが できるのか」と責められてこまるといら話などあ 時には聞くことがある。

ロボット技術を自動化技術の一部と考えるのは 何も中国のプロジェクトだけではない。日本でも かなりの人がそのように考えているように思う。 私自身す「こらいう作業ロボットで自動化できな いか」といら類の技術相談をよく受けることがあ る。またメンテナンスロボット、掃除ロボット、 介護ロボット、医用ロボット、福祉ロボットなど、 いろいろな適用される分野の名称を頭に付けた口 ボット用語が使われているが、これらのどれもが それぞれの分野の作業を人の代わりにやってくれ る自動化システムとしてロボットを考觉ての名称 である。

ある実用的なシステムを開発しよらとするとさ、 そこにはそれぞれに固有の開発目的がある。無駄 なくかつ経済的にこの目的に答えるシステムを構 築していくのが個々のシステムを開発する祭の基 本である。システム開発の目標がロボットの研究 
の目指すところと一致する時、ロボットはそのシ ステムを実現する際の有力な解を与えることにな ろら。しかし常にこらした条件が満たされるとは 限らず、口ボット技術が必ずしも目標とするシス テムの最適解とならないことも多い。例壳ば上記 の生産ラインの自動化システムを構築する場合を 考えると、その目的とするところは生産性の高い ラインの構築であり、そこに要求されるシステム 要素としての機械は、できるだけ早く、確実に、 かつ低コストで作業が行觉る機械である。一般に この要求に答える機械を開発する実用技術は先端 的なロボット技術ではなく、剛性の高い機構を設 計する技術であったり、あるいは高速位置決めサ 一ボ技術であったりする。そこで自動化ラインを 構築すると言ら立場からは、機構設計やサーボ技 術を研究した方が効果的と言うことになる。口ボ ットを自動化技術として捉える場合は、こうした
サーボ技術等もロボット技術の一部と言うことに なるがそれではロボット技術の特長がなくなる。

ではロボット工学あるいはロボット学とは何か と言うことになるが、私は用途を問わずに生体の 機能を見つめてその工学的解积を図り、引いては それから工学系の新たな設計思想を見いだすこと ではないかと考えている。こうした姿勢を取るこ とによってはじめて従来の機械工学や、制御工学 などの既存の学問領域から独立した、ロボット工 学固有の学問の世界が生まれるのではないかと思 万。

本号では生体の特長を重視する立場から精力的 にロボットの研究に取り組んでいる専門家の諸先 生に執筆を和願いし、生体とロボットを特集した。 本特集号からオーソドックスなロボット工学にお ける研究開発の最新動向を読み取っていただけれ ば、企画者の一人として望外の幸いである。 